\title{
THE FIRST EOCENE SPECIES OF THE GENUS CRYPTOPHAGUS (COLEOPTERA, CLAVICORNIA, CRYPTOPHAGIDAE)
}

\author{
G. Yu. Lyubarsky'1, E. E. Perkovsky² \\ ${ }^{1}$ Zoological Museum of Moscow State University \\ Bol'shaya Nikitskaya str., 6, Moscow, 103009 Russia \\ E-mail: lgeorgy@rambler.ru \\ 2 Schmalhausen Institute of Zoology, NAS of Ukraine, \\ B. Chmielnicky str., 15, Kyiv, 01601 Ukraine \\ E-mail:perkovsk@gmail.com
}

Received 22 October 2010

Accepted 10 November 2011

The First Eocene Species of the Genus Cryptophagus (Coleoptera, Clavicornia, Cryptophagidae). Lyubarsky G. Yu., Perkovsky E. E. - Based on a fossil specimen from the Late Eocene Rovno amber (Ukraine), Cryptophagus harenus Lyubarsky et Perkovsky, sp. n., an Eocene species of this genus is described. The new species is similar to the extant desert species Cryptophagus desertus Lyubarsky and C. recticollis Solsky, differing by the large callosity occupying 1/4 length of lateral margin of pronotum.

Key words: Cryptophagidae, Cryptophagus, Late Eocene, Rovno amber.

Первый эоценовый вид рода Cryptophagus (Coleoptera, Clavicornia, Cryptophagidae). Любарский Г. Ю., Перковский Е. Э. - Из позднеэоценового ровенского янтаря (Украина) описан Cryptophagus harenus Lyubarsky et Perkovsky, sp. n. - первый эоценовый вид рода. Вид наиболее близок к современным пустынным видам Cryptophagus desertus Lyubarsky и C. recticollis Solsky; отличается от них большой мозолью, занимающей четвертую часть длины переднеспинки.

Ключевые слова: Cryptophagidae, Cryptophagus, поздний эоцен, ровенский янтарь.

\section{Introduction}

The family Cryptophagidae is a group of small beetles with about 800 described species placed in about 50 genera and represented in all biogeographic realms. Both adults and larvae are commonly found on mold, fungi, under bark as well as in decaying vegetation. Atomaria Stephens and Hypocoprus Motschulsky were collected in large mammals' dung (for example, A. hislopi Wollaston was collected in dung of an elk). Some genera of Cryptophagidae live in nests of social Hymenoptera, birds and mammals. The species of Cryptophagus Herbst are collected from nests of bumblebees, bees, vespid wasp, and ants. Spaniophaenus Reiter was collected from a termite nest. Micrambe Thomson is sometimes found in nests of gregarious caterpillar (Falcoz, 1929). Some species of Cryptophagus are found in wool and nests of rodents (Woodroffe, Coombs, 1961; Barrera, Martinez, 1968).

Species of Catopochrotus Reitter, Myrmedophila Bousquet, Spavius Motschulsky, Hypocoprus inhabit in ant nests. Species of Telmatophilus Heer apparently feed on flower heads of certain aquatic plants. One species of Atomaria Stephens is a sugar beet pest. Cryptothelypterus Leschen et Lawrence feeds on fern spores (Leschen, Lawrence, 1991). Several species of Cryptophagus Herbst are found in stored products. Hypocoprus Motschulsky is associated with drier habitat. Recent review of natural history of the family, food preferences and habitat is given in Leschen (Leschen, 1996) and Lyubarsky (Lyubarsky, 2002).

The fossil Cryptophagidae is insufficiently known, like many other families Cucujoidea. The oldest described cryptophagid species is the Upper Cretaceous Nganasania khetica Zherikhin (Zherikhin, 1977) described from fossil resin of Northern Siberia; questionable cryptophagid was reported from the Lower 
Cretaceous Lebanese amber (Kirejtshuk, Azar, 2008). Cretaceous Cryptophagites Ponomarenko (Ponomarenko, Ryvkin, 1990) is not Cryptophagidae. Representative of Cryptophagidae identified only to the family level was found in the lowermost Eocene French amber (Kirejtshuk, Nel, 2008). Representatives of recent cryptophagid genera, viz., Cryptophagus, Antherophagus Dejean, Atomaria, Micrambe, Ephistemus Stephens and Telmatophilus are reported from the Late Eocene Baltic amber found in former East Prussia (now Kaliningrad region) (Klebs, 1910; Spahr, 1981; Kubisz, 2000); the latter genus is also reported from the Bitterfeldian amber (Hieke, Pietrzeniuk, 1984).

Rovno amber is a southern coeval analogue of famous Baltic amber (Perkovsky et al., 2007; Perkovsky et al., 2010). Amber collection of the Institute of Zoology, NAS of Ukraine(SIZK) contains more than 800 inclusions of beetles from the Late Eocene Rovno amber, but the first cryptophagid species Rovno amber (Micrambe sarnensis Lyubarsky et Perkovsky (Lyubarsky, Perkovsky, 2010) from Rovno amber was found only two years ago.

The new species belongs to the family Cryptophagidae: tarsal formula, 3-segmented club of antennae, closed procoxal cavities. The new species showing antennal insertions exposed in dorsal view; pronotum with well developed marginal callosity; mesocoxal cavity closed laterally by the sternum; ventrite 1 longer than remaining ventrites; puncturation of elytra confused. These characters are indicative of the genus Cryptophagus Herbst (Cryptophaginae). Representatives of Cryptophagus are found in all biogeographic realms. The genus Cryptophagus includes the 137 species from the Palaearctic Region (Johnson et al., 2007).

Photographs were taken at the Paleontological Institute, Russian Academy of Sciences (Moskow) by A. V. Mazin and the second author at the microscope Leica MZ 16.

Family CRYPTOPHAGIDAE Kirby, 1837

Subfamily CRYPTOPHAGINAE Kirby, 1837

Genus Cryptophagus Herbst, 1863

\section{Cryptophagus harenus Lyubarsky et Perkovsky sp. n.}

Material. Holotype, SIZK No K-8224, Klesov, Rovno amber, Late Eocene. Syninclusions: Psychodidae, leg of Tipuloidea, two mites on the of beetle (Uropodina, ?Trematuridae) (fig. 1, $2 a$ ).

Description. Body broadly elongate (fig. 1, 1; 2), slightly convex; head, pronotum, and elytra reddish brown. Elytra slightly convex, covered with almost appressed pubescence.

Head transverse, of normal size, with hemispherical, somewhat coarsely facetted eyes, strongly and sparsely punctured. Antennae long, slender, with club reaching beyond base of pronotum, joints 1-3 elongate, joints 4-8 slightly conical, almost equal in length, 9th and 10th transverse, 11th obliquely oval, joints 9-11 equal in width.

Pronotum distinctly transverse, barely 1.6 times broader than long, moderately strongly and densely punctured (1 diameters apart), an individual puncture almost equal to facette diameter. Pronotum without sublateral line, somewhat convex, with subparallel sides, with a single lateral tooth. Sides finely margined, anterior edge weakly sinuate. Callosity occupying at most one-fourth of side margin, with a small, elongate-oval patch of bare surface invisible from above; caudolateral corner obtuse angular, callosity without point. Lateral tooth far behind middle of lateral margin. Posterior corners obtuse, base round, slightly sinuate, basal groove narrow.

Scutellum small, transverse. Elytra oval, humeral corners rounded, shoulders a little broader than maximum breadth of pronotum, 1.8 times as long as wide and 3.1 times as long as thorax, moderately convex, slightly flattened behind scutellum, with slightly rounded sides and a narrowly rounded apex, puncturation more strong as, yet more sparse than that on pronotum.

Length $3.1 \mathrm{~mm}$.

Cryptophagus harenus sp. $\mathrm{n}$. is most similar to the recent Cryptophagus desertus Lyubarsky and $C$. recticollis Solsky: all three species easily separated from other Cryptophagus by lateral tooth situated far behind middle of pronotum, in $1 / 4$ length to posterior angle.

Et y mology. Harenus (Latin) - arenaceous. 

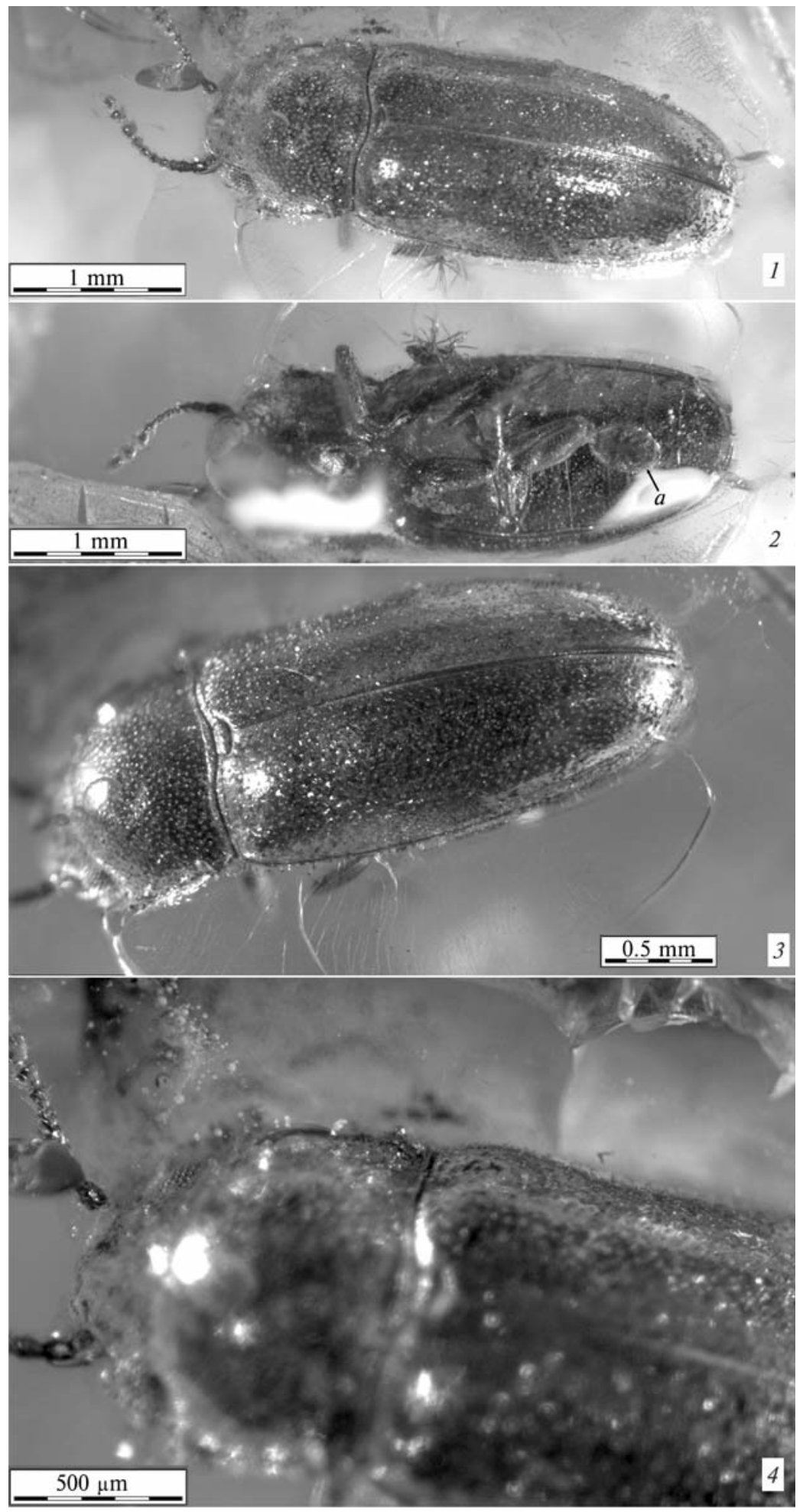

Fig. 1. Cryptophagus harenus Holotype (SIZK K-8224, Klesov, Rovno amber, Late Eocene): 1 - body, dorsal; 2 - body, ventral $(a$ - mite $) ; 3$ - elytrae; 4 - front part, dorsal.

Рис. 1. Cryptophagus harenus голотип (инв. номер К-8224 коллекции Института зоологии НАН Украины, Киев, Клесов, ровенский янтарь, поздний эоцен): $1-$ вид сверху; $2-$ вид снизу $(a-$ клещ); 3 - надкрылья; 4 - пронотум сверху. 


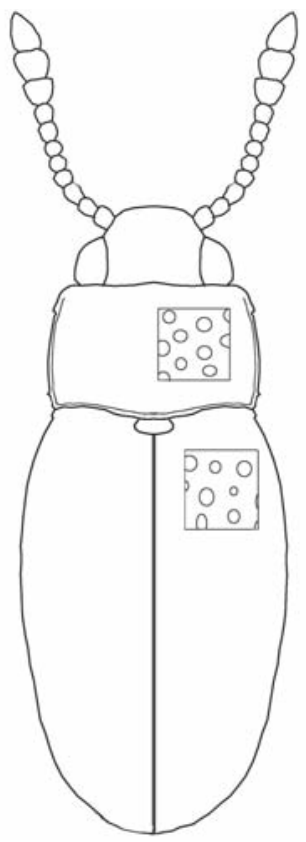

Fig. 2. Cryptophagus harenus, dorsum of the body.

Рис. 2. Cryptophagus harenus, дорсальная сторона тела.

Key to species of the genus Cryptophagus with lateral tooth situated far behind middle of pronotum

Таблица для определения видов рода Cryptophagus с латеральным зубцом, расположенным далеко за серединой пронотума

1. Callosity short, its length occupying $1 / 8-1 / 7$ length of lateral margin of pronotum, with point, angle between bare surface of callosity and longitudinal axis of body more than 55 degrees. Lateral tooth strong.

- Callosity normal, its length occupying $1 / 4$ length of lateral margin of pronotum, without point, angle between bare surface of callosity and longitudinal axis of body less than 55 degrees. Lateral tooth weak. Length of body $3.1 \mathrm{~mm}$. Rovno amber.

C. harenus sp. $\mathrm{n}$

2. Pronotum relatively short, its length less than 0.3 length of elytra. 3rd segment of antennae equal to $2^{\text {nd }}$. Eyes flat. Length of body 1.8-2.3 mm. Kazakhstan (Atyrau (formerly Guryev) Province; Lake Balkhash area); Uzbekistan (Bukhara Province, Kyzyl-Kum Desert). C.recticollis Solsky

- Pronotum normal, its length more than 0.3 length of elytra. 3rd segment of antennae distinctly (more than 1.3 times) longer than 2nd. Eyes normal in shape. Length of body 2.4-3.8 mm. Kazakhstan (Atyrau (formerly Guryev) Province, Mongolia (South Gobi aimak), China (Alashan Plateau).

C. desertus Lyubarsky

C. desertus and C. recticollis inhabit the holes of big chickweed (Rhombomys opimus (Lichtenstein) (Lyubarsky, 2002).

Discussion. Fauna of Rovno amber forest indicates more xeric environments than those known for the Baltic amber forest (Perkovsky et al., 2007, 2010). Finding of the new cryptophagid beetle related to the recent desert species is indicative of very xeric environment in at least a part of open territories adjacent to the amber forest. of mites.

Authors are indebted to A. P. Rasnitsyn for continuous help and A. A. Khaustov for the determination

Barrera A., Martinez A. Nuevo criptofagido mexicano: Cryptophagus bolivari nov. sp. (Ins. Col.) // An. Esc. Nac. Cienc. Biol. Mex. - 1968. - 17. - P. 151-156.

Falcoz L. Tableaux analytiques des coleopteres de la faune Franco-Rhenane (France, Hollande, Belgique, Region rhenane, Valais): Famille XXXIII. Cryptophagidae // Miscellanea Entomol. - 1929. 31-32. - P. 1-197.

Hieke F., Pietrzeniuk E. Die Bernstein-Käfer des Museums fur Naturkunde, Berlin (Insecta, Coleoptera) // Mitt. zool. Mus. Berl. - 1984. - 60 (2). - S. 297-326. 
Johnson C., Otero J. C., Leschen R. A. B. Family Cryptophagidae // A catalogue of Palaearctic Coleoptera vol. 4 / Ed. I. Löbl, A. Smetana. - Steenstrup : Apollo Books, 2007. - P. 513-531.

Kirejtshuk A. G., Azar D. New taxa of beetles (Insecta, Coleoptera) from Lebanese amber with evolutionary and systematic comments // Alavesia. - 2008. - 2. - P. 15-46.

Kirejtshuk A. G., Nel A. New taxa of Polyphaga from the Lowermost Eocene French amber (Insecta: Coleoptera) // Ann. Soc. entomol. France. - 2008. - 44 ( 4). - P. 419-442.

Klebs $R$. Über Bersteineinschllüsse im allgemeinen und die Coleopteren meiner Bernsteinsammlung // Schriften der physikalisch-ökonomischen Gesellschaft zu Königsberg i Pr. - 1910. - 5. - S. 217-242.

Kubisz D. Beetles in the collection of the Museum of Amber Inclusions, University of Gdansk, with description of Colotes sambicus sp. n. (Coleoptera: Melyridae) // Polskie Pismo Entomologiczne. - 2001. 70. - P. 259-265.

Leschen R. A. B. Phylogeny and revision of the genera of Crypophagidae (Coleoptera: Cucujoidea) // The University of Kansas. Science Bulletin. - 1996. - 55, N 15. - P. 549-634.

Leschen R.. A. B., Lawrence F. J. Fern sporophagy in Coleoptera from the Juan Fernandez Islands, Chile, with descriptions of two new genera in Cryptophagidae and Mycetophagidae // Syst. Entomol. 1991. - 16. - P. 329-352.

Lyubarsky G. Cryptophaginae (Coleoptera: Cucujoidea: Cryptophagidae): diagnostics, arealogy, ecology. Moscow : Moscow Univ. Publ., 2002. - 421 p.

Lyubarsky, G. Yu., Perkovsky, E. E. First Eocene species of the genus Micrambe (Cryptophagidae: Coleoptera, Clavicornia) // Vestnik zoologii. - 2010. - 44, N 3. - P. 275-279.

Perkovsky E. E., Rasnitsyn A. P., Vlaskin A. P., Taraschuk M. V. A comparative analysis of the Baltic and Rovno amber arthropod faunas: representative samples // African Invertebrates. - 2007. - 48. - 1. P. 229-245.

Perkovsky E. E., Zosimovich V. Yu., Vlaskin A. P. Rovno Amber // Biodiversity of fossils in amber from the major world deposits / Ed. David Penney. - Manchester : Siri Scientific Press, 2010. P. 116-136.

Ponomarenko A. G., Ryvkin A. B. Beetles Scarabeida // Late Mesosoic insects of Eastern Transbaikalia Ed. A. P. Rasnitsyn. - Moscow : Nauka, 1990. - P. 39-87. - Russian : Пономаренко А. Г., Рывкин А. Б. Жуки. Scarabaeida.

Spahr U. Systematischer Katalog der Bernstein- und Kopal-Käfer (Coleoptera) // Stuttgarter Beiträge zur. Naturkunde. Ser. B. - 1981. - 80. - S. 1-107.

Woodroffe G. E., Coombs C. W. A revision of the North American Cryptophagus Herbst (Coleoptera, Cryptophagidae) // Misc. Publ. Entomol. Soc. Am. - 1961. - 2. - P. 179-211.

Zherikhin V. V. Families Cerophytidae, Acanthocnemidae, Cryptophagidae, Lathridiidae, Attelabidae, Curculionidae // Mesozoic Coleoptera / Ed. B. B. Rohdendorf. - Moscow : Nauka, 1977. P. 130-134, 135-142, 176-182. - (Tr. Paleontol. In-ta AN SSSR ; T. 161). - Russian : Жepuхин В. В. Семейства Cerophytidae, Acanthocnemidae, Cryptophagidae, Lathridiidae, Attelabidae, Curculionidae. 